\title{
The Application of GPS (Global Positioning System) and SMS Gateway on Hepinar "Helm Pintar" Arduino Microcontroller Based as a Post-Accident Solution
}

\author{
Malikul Fanani, Kukuh Priambodo, Iklil Sulaiman, Sumardi ${ }^{1}$
}

\begin{abstract}
In Indonesia, the number of death of accident is still pretty high with most of $70 \%$ the traffic accident is motorcycle driver who is late in getting aid and the head injury is the first order of all types of experiencing by the accident victim. Prehospital Care is an emergency service when the victim is firstly found, during the process of the transportation until the patient arrives at the hospital Thus, the purpose of this research is the application of GPS (Global Positioning System) and SMS gateway on the safety helmet in order to increase the aid post-accident. The application of GPS has an advantage to receive data from the satellite which next will be stored on arduino microcontroller. Microcontroller will retrieve the driver location data in the forms of latitude, longitude and time. Next, the driver location will be sent by microcontroller via SMS gateway service to the nearest hospital and the victim's family to make the evacuation process easy. This research is tested along the travel of Jember-Lumajang regency. The result of this research is the GPS application on the safety helmet can be applied well. The transmission of driver position coordinate data if the accident happened via sending media of SMS can be applied along with GSM signal from the provider so that the SMS sending works well.
\end{abstract}

Keywords-Helmet, GPS (Global Positioning System), SMS Gateway, Arduino, GSM

\section{INTRODUCTION}

$\mathbf{T}$ raffic accident is a complex problem and needs a special attention. It can be seen by the existence of the increasing number of accident year by year. The number of people dying caused by the traffic accident in the last quarter of 2016 approaches to 6383 , it is mostly because of motorcycle traffic accident. Accident victim can be worse or lead to death if it is not handled fast in the first hour in a rescue of accident victim. Prehospital Care is an emergency service when the victim is firstly found, during the transportation process until the patient arrives at the hospital. [2]. On the prehospital period, if at the first place occurrence the victim does not get an optimal help suitable as the needs, it will cause a risk problem of permanent disability even a death.

Globally, there are around 1.3 million of people dying each year caused by the traffic accident and this amount will increase to 1.9 million in 2020. In Indonesia, the disability proportion and the death number because of accident is still high enough which is most of $70 \%$ traffic accident victim are

${ }^{1}$ University of Jember, Kalimantan Street No. 37, Jember, East Java 151910201076@students.unej.ac.id a motorcycle driver who is late in getting a first aid and the head injury is the first order of all types of injuries experienced by the traffic victim [3][4].

The main component in giving the first aid in an accident, both massive accident and single vehicle accident is communication. CCTV technology and frequent monitoring from the police is less effective because there is a limitation. As like the CCTV which does not exist in an isolated area and only specialized in an urban area. Then, the monitoring or surveying every road frequently by the police will be also not effective because the accident can not be predicted.

Based on the explanation above, it requires a new technology which can communicate the accident victim with the police and the nearest hospital to fasten the evacuation and to do a first aid. Smart Helmet (HEPINAR, Helm Pintar), is a new technology on the safety helmet which can be used to know the user position when the helmet is used and may become a communication media between the user with the near hospital if there is an accident. With this technology, the worker can predict the time travel and the location place to make the evacuation process easy if there is an accident happened.

The technology is a navigation tool based on the satellite which is more known as The Global Positioning System (GPS) [5] [6]. The GPS is a global coordinate system which can help to determine the coordinate of an object wherever in the world of both latitude and longitude coordinate If the safety helmet is applied in this technology, the driver will be monitored the coordinate by the GPS if an accident happened. The position data of the driver will be recorded by a microcontroller to be processed and transmitted automatically. This data transmission uses a GSM module [7].

On this research it will be designed a control and monitoring system of safety helmet by real time and automatic. The system consists of the GPS, Arduino microcontroller and GSM module. This research aims to construct a monitoring system of the driver if an accident happened and the most important is it can give the first aid quickly and accurately.

\section{METHODS}

Two parts of the system that will be designed, constructed, analyzed, and tested are: the first part is a designing and constructing of navigation tool on the safety helmet. The second part is an arduino programming in order to connect with the GPS and SMS Gateway.

The general illustration of a post-accident notification system on this research can be seen at Figure 1 . 


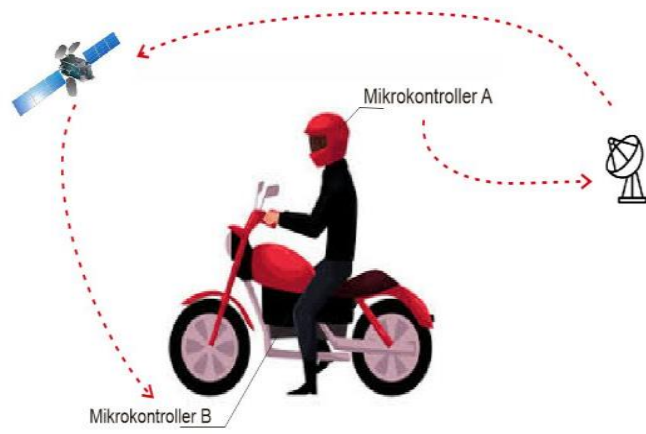

Figure 1. The General Illustration of Navigation System on the Safety Helmet

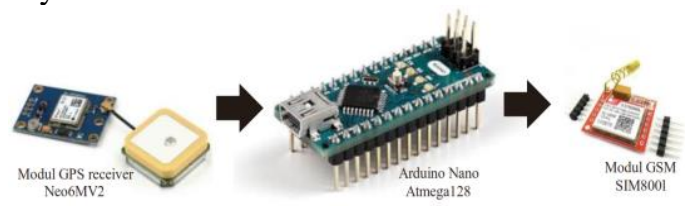

Figure 2. Navigation System on the Safety Helmet

Steps that will be done in the designing and the construction of three parts of this system are: (1) The first part is designing and constructing a notification system which is located in the helmet: the post-accident notification system on the helmet consists of GPS receiver, Arduino Nano microcontroller [8], and GSM Module. The working process of the notification system on this safety helmet is if the emergency button on the helmet is pressed, the GPS receiver will receive a signal from the GPS satellite reading. The GPS receiver will calculate the position coordinate and time travel from the nearest hospital. The microcontroller is programmed to obtain data from the GPS receiver which consists of position data and time travel toward the nearest hospital in the evacuation process (Figure 2). Then, microcontroller will transmit the data through GSM module based on SMS gateway in the nearest hospital number and the victim's family. (2) The second part is receiving system through SMS. Smartphone of the hospital or the victim's family will receive the position data and time travel in the safety evacuation process in the form of SMS. The position of accident victim will be represented by a point of digital map.

\section{RESULTS AND DISCUSSION}

The research results are from the construction of hardware and software, and the performance testing from every part of the circuit and the overall system. The purpose of this testing is to find out the performance from every part of the overall circuit system. The testing is done in two steps. The first step is done at Basic Electricity Laboratory, Faculty of Engineering, University of Jember. The second step is done a testing by real time along the travel of Jember-Lumajang.

Hardware which is made consists of 2 (two) parts which are: a system on the safety helmet and a system on the android of the hospital. The block diagram figure of the hardware can be seen at figure 4 .

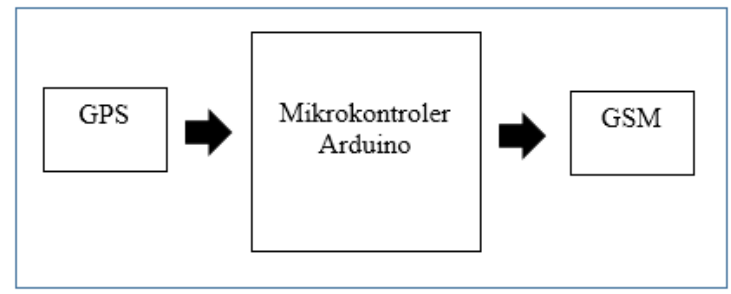

Figure 4. Communication system on the helmet

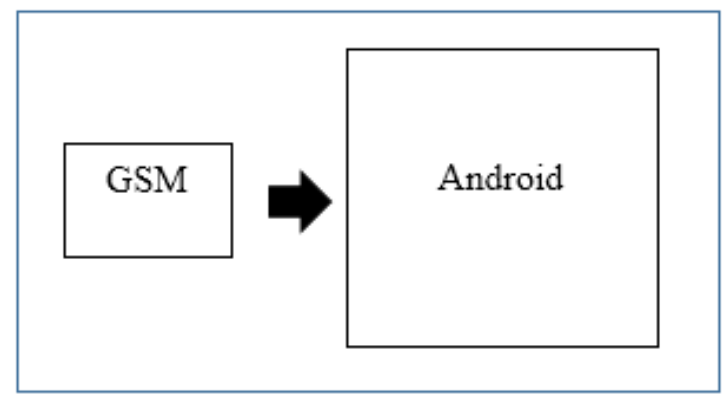

Figure 5. Communication system on the Android.

Software is done by using the arduino programming language to program the microcontorller, while to receive the SMS at the android is using the default application of the handphone. The flowchart of the software can be seen at figure 5.

Software consists of 2 parts which are: microcontroller program construction which will be located on the safety helmet. Microcontroller program uses arduino software by using arduino programming language. The purpose of this programming is to do a reading of coordinate location of the driver if the driver is facing an accident from the GPS then transmitting to the nearest hospital and the family. Data is transmitted in the form of SMS by using GSM module. (2) which is doing an arduino programming in order to send the message to the smartphone [9]. The purpose of this programming is to be able to do a reading on the link which is directly connected to Google Map. Google Map is a service of web maping which is developed by Google. This service gives the image of the satellite and road map, so that the driver position in the accident will be exposed in the digital map.

A. Microcontroller Programming on HEPINAR.

This microcontroller program on HEPINAR is made to receive data from the GPS and transmit the data to the nearest family and hospital. The data transmitting is via SMS by using GSM module. GPS receiver will receive data from the satellite as follows:

$\begin{array}{lll}-8.185287 & 113.683741 & 4 \text { hours } 43 \text { minutes } \\ -8.188799 & 133.659931 & 4 \text { hours } 37 \text { minutes } \\ -8.197259 & 113.632400 & 4 \text { hours } 29 \text { minutes }\end{array}$

Data coming from the GPS are not all used. The first purpose of this research is only to determine the driver position so that the data obtained is only the position data. The task of microcontroller is obtaining data required which are longitude and latitude coordinate and standard time of UTC (UTC Time). 


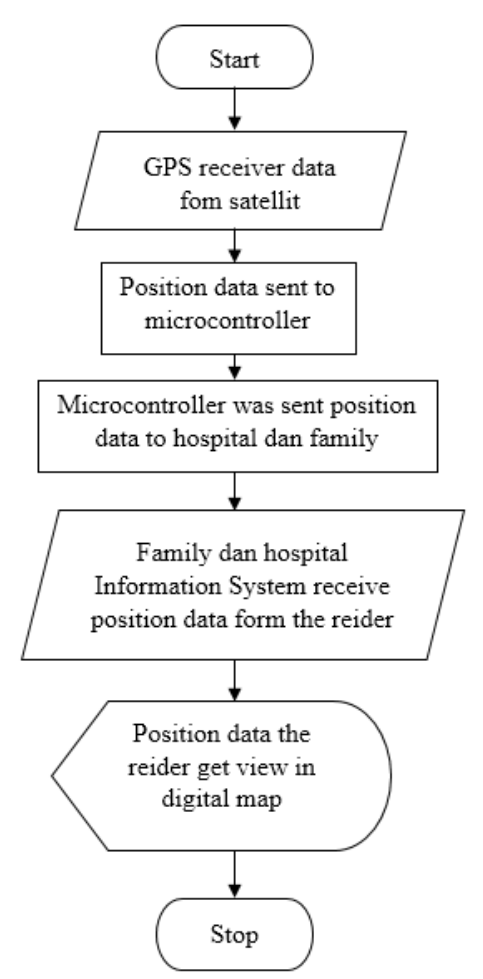

Figure 5. Flowchart of Software System

Latitude and longitude coordinate data are required to determine the driver position and the time data (UTC time) is required to know the fastest route for evacuation.

After the microcontroller has obtained data required, the thing which needs to be done is the data will be transmitted via SMS to GMS number of the hospital and family [10][11]. SIM Card provider which is used in this research is Indosat. The command standard used is AT-Command, while the protocol is called as unit data protocol (UDP) [12]. On this research, it uses GSM SIM800L module, so that to be able to send and receive messages, it uses the available library.

Commands to send messages

\section{serialSIM800.write(“AT+CMGS=|"000〉’|r\n”)}

Where 000 is a number of character pair of UPD data which want to be transmitted. In the UDP data later, the sending destination number and SMS message we want are saved.

Commands to send messages

$$
\text { serialSIM800.read(“AT+CMGS=l”000〉”'\\n”) }
$$

Where 000 is SMS index number that wants to be read in the storage memory (SIM card).

\section{B. Program on the Arduno}

The program on the arduino uses arduino program. When the smartphone receive a SMS consisting link, and the link will be directly connected to google map. Google map program is a viewer program of digital map. To see the safety helmet position used by the driver on the map, then Google Maps have to be connected with internet.

The flowchart of the program at the monitoring post is as follows: After the SMS in the form of position data has been
Table 1. Hardware Testing Result

\begin{tabular}{ll}
\hline Parts of Tool & Description \\
\hline $\begin{array}{l}\text { Minimum system of } \\
\text { microcontroller }\end{array}$ & Works well \\
\hline $\begin{array}{l}\text { Microcontroller interface } \\
\text { with GPS }\end{array}$ & Works well \\
\hline $\begin{array}{l}\text { Microcontroller interface } \\
\text { with GSM }\end{array}$ & Works well \\
\hline Android interface with GSM & Works well \\
\hline $\begin{array}{l}\text { Tool Installation on the } \\
\text { Helmet }\end{array}$ & Installed in the cork helmet \\
\hline
\end{tabular}

\begin{tabular}{ll}
\multicolumn{2}{c}{ Table 2. Hardware Testing Result } \\
\hline Parts of Tool & Description \\
\hline $\begin{array}{l}\text { Reading program of GPS } \\
\text { data }\end{array}$ & Works well \\
\hline $\begin{array}{l}\text { Data receiving program with } \\
\text { SMS }\end{array}$ & Works well \\
\hline $\begin{array}{l}\text { Data reading on Google } \\
\text { Maps }\end{array}$ & Works well \\
\hline
\end{tabular}

received by the monitoring post GSM, the monitoring post GSM will be shown codes as follows: +CMTI: "SM",1, the code indicates that there is a SMS inbox/ received.

\section{Tool Testing}

Hardware testing is done part by part, with a purpose to make easy to track the error if the error happened, after all of the parts have worked well then the system is overall tested. Hardware testing result can be seen at Table 1. Software which is tested is a program on the microcontroller and computer. Software testing result is figured at Table 2. The system testing overall is done along the travel of JemberLumajang Regency. The result of the testing and the measurement of helmet position coordinate is figured at Table 3 , while the visualization of safety helmet position trace on the smartphone screen can be seen at Figure 6.

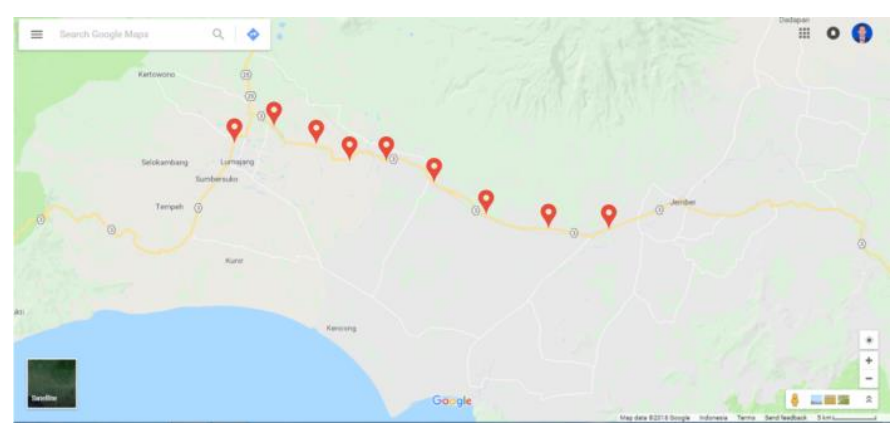

Figure 6. Visualization Result of Experiment Data on Google Maps.

\section{CONCLUSION}

From the whole discussion in this research, it can be concluded that the GPS application on the safety helmet monitoring system can be applied well because the coordinate position data of GPS satellite can be detected well on the Google Maps program. The transmission of driver position coordinate data if the accident happened via sending media of SMS which can be applied along with GSM signal from the provider so that the SMS sending works well. This technology might help the evacuation process faster because the driver position if the accident happened can be known early 
Table 3. Data Result of Safety Helmet Location Experiment

\begin{tabular}{|c|c|c|c|c|c|}
\hline Data & Location & Link & Latitude & Longitude & Time \\
\hline 1 & Kaliwates & $\begin{array}{l}\text { http://www.google.com/maps/p } \\
\text { lace/-8,185287,113,683741 }\end{array}$ & -8.185287 & 113.683741 & 4 hours 43 minutes \\
\hline 2 & Sempusari & $\frac{\text { http://www.google.com/maps/p }}{\text { lace/-8,188799,133,659931 }}$ & -8.188799 & 133.659931 & 4 hours 37 minutes \\
\hline 3 & Jubung & $\frac{\text { http://www.google.com/maps/p }}{\text { lace/-8,197259,113,632400 }}$ & -8.197259 & 113.632400 & 4 hours 29 minutes \\
\hline 4 & Rambipuji & $\begin{array}{c}\text { http://www.google.com/maps/p } \\
\text { lace/-8,214291,113,604039 }\end{array}$ & -8.214291 & 113.604039 & 4 hours 32 minutes \\
\hline 5 & Langkap & $\frac{\text { http://www.google.com/maps/p }}{\underline{\text { lace/-8,202281,113,554476 }}}$ & -8.202281 & 113.554476 & 4 hours 17 minutes \\
\hline 6 & $\begin{array}{l}\text { Tanggul } \\
\text { Kulon }\end{array}$ & $\begin{array}{c}\text { http://www.google.com/maps/p } \\
\text { lace/-8,162298,113,446035 }\end{array}$ & -8.162298 & 113.446035 & 4 hours 15 minutes \\
\hline 7 & Sadengan & $\frac{\text { http://www.google.com/maps/p }}{\text { lace/-8,129274,113,402623 }}$ & -8.129274 & 113.402623 & 4 hours 24 minutes \\
\hline 8 & Sukosari & $\frac{\text { http://www.google.com/maps/p }}{\text { lace/-8,114020,113,313868 }}$ & -8.114020 & 113.313868 & 4 hours 27 minutes \\
\hline 9 & $\begin{array}{l}\text { Galdak } \\
\text { Serang }\end{array}$ & $\begin{array}{c}\text { http://www.google.com/maps/p } \\
\text { lace/-8,096567,113,268592 }\end{array}$ & -8.096567 & 113.268592 & 4 hours 18 minutes \\
\hline 10 & $\begin{array}{l}\text { Tompok } \\
\text { Saren }\end{array}$ & $\frac{\text { http://www.google.com/maps/p }}{\text { lace/-8,122360,113,219999 }}$ & -8.122360 & 113.219999 & 4 hours 20 minutes \\
\hline
\end{tabular}

\section{REFERENCES}

[1] Korlantas Polri (2017) Data Kecelakaan Lalu Lintas Tahun 2016 http://korlantas-irsms.info

[2] Margareta. (2012). Buku Cerdas P3K:101 Pertolongan Pertama Pada Kecelakaan. Yogyakarta: Niaga Swadaya

[3] Yusharmen. 2008. Petunjuk Teknis Surveilans Gangguan Akibat Kecelakaan Dan Cedera Lalu Lintas. Direktorat jenderal PP \& PL Direktorat Pengendalian Penyakit ...Tidak menular Subdit Kecelakaan Dan Cedera. Jakarta: Departemen Kesehatan Republik Indonesia.

[4] Yusherman. 2008. Pedoman Pengendalian Faktor Resiko Gangguan Akibat Kecelakaan Dan Cedera (Seri Kecelakaan Lalu Lintas). Direktorat jenderal PP \& PL Direktorat Pengendalian Penyakit Tidak menular Subdit Kecelakaan Dan Cedera. Jakarta: Departemen Kesehatan Republik Indonesia.

[5] Budiawan, Tiyo and Santoso, Imam and Zahra, Ajub Ajulian.2011.Mobile Tracking GPS Global Positioning System) Melalui Media SMS (Short Message Service). Undergraduate thesis, University Diponegoro.
[6] Z.A. Abidin, Penentuan Posisi GPS dan Aplikasinya, Pranya Paramita, Jakarta, 2007,p.101.

[7] A. Sunyoto, Pemanfaatan Modul GPS Receiver dan Telepon Selular untuk Wide Area Vehicle Tracking, Prosiding Seminar Nasional Teknologi (SNT 2007), Jakarta, 2007.

[8] Yusro, Muhammad dan Firmansyah Imam.2009.Modul Pelatihan Mikrokontroler at atmega8535.pt bukaka teknik utama. Jakarta.

[9] W. Endah, W. Rachma, P. Rian, W. Susilo, U. Umuhani, I.W.S Wicaksana, Perbandingan Transfer Rate GSM pada Handphone sebagai Device Access dan Handpone sebagai Modem, http://openstorage.gunadarma.ac.id/ mwiryana/KOMMIT/per-artikel/0103-013.pdf, 2011.

[10] J, Raper, G. Gartner, H. Karimi, C. Rizos, J. Locat. Base. Serv. 1 (2007) 5 .

[11] S.v.d. Spek, J.v. Schaick, P.d. Bois, R.d. Haan, Sensors 9/4 (2009) 3033.

[12]N. Shoval, Cities, 25/1 (2008) 21 